\title{
Social Inclusion of Jyapus in Newar Community
}

\begin{abstract}
Jpapus, one of the caste groups of Newar caste hierarchy, has been living with nears in the lalitpur city. The major population of Jyapus is found in the selected roles of city i. e. Chhayabahal, Lukhusi, Tanani and Nakabahil. This study focused on the social inclusion of Jyapus from socio-cultural and economic dimensions. To collect primary data on social inclusion of Jyapus researcher has had selected 231 households and applied data collection tolls such as Interview schedule, non-participant observation and Key- informants' interview. By using such data collection toll's researchers had found that major population of the Jyapus prefers to live in nuclear family. This study reveals that, among 231 respondents 45 respondents were unmarried so that they are excluded from the total universe. So our universe is limited in 186 respondents. Thus, in the survey, 116 of the Jyapu respondents did love marriage. In regard with the educational status of the Jyapus majority, 150 Jyapus of the sample population were educated. In the study area, most of the Jyapus left their traditional work as agriculture and most of the Jyapus are nowadays doing services in different offices like other high caste Newars. One hundred thirty households in the study area used both Nepali and Newari language. Most of the 99 Jyapus are the followers of Buddhist religion. They also follow life cycle ceremonies as par with the other Newara in the study area. 187 Janus were not facing untouchability practiced in the study area by the other Newars. Similarly, majority, 185, Jyapus were participating in a different organization, so they are not excluded in the study area. While celebrating machinendra nath jatra they also celebrate together abd there is no any other ways and places for the celebration. This indicates that they are included. In addition, during the feast they also eat together with other Newars.
\end{abstract}

Key Words: Inclusion, Newars, Jyapus, Untouchability, Discrimination

\section{Introduction/Background}

Nepal, officially the Federal Democratic Republic of Nepal, is a country in South Asia and, as of 2010, the world's a recent nation to become a Republic. It is located in the Himalayas and bordered to the north by the People's Republic of China, and to the south, east, and west by the Republic of India. Nepal is a country of highly diverse and rich geography, culture, 
and religions. The diversity of ethnic groups and their cultural heritage and beliefs are largely influenced by the Aryan and Tibetan culture. Being a land of multi-castes, religions, languages, beliefs, etc, Nepal has never faced conflict between racial groups.

Nepal is roughly trape zoidal shape, 800 kilometers (497 mi) long and 200 kilometers (124mi) wide, with an area of $147,181 \mathrm{~km} 2(56,827 \mathrm{sq} \mathrm{mi})$. Nepal is commonly divided into three physiographic areas: the Mountain, Hill and Terai Regions. These ecological belts run east-west and are vertically intersected by Nepal's major, north to south flowing river systems. The mountainous north has eight of the world's ten highest mountains, including the highest, Sagarmatha, known in English as Mount Everest. The fertile and humid south is heavily urbanized. Nepal is such a country where Indo-Aryan and Tibeto-Burman people share the same land, live harmoniously and still live their lives with their own ways.

The Himalayas and Upper Hills of Nepal is inhabited by Tibeto-Burman speaking people; Sherpa, Tamangs etc, who shares the culture and traditions influenced by the Tibetans. Brahmins, Chhetris, Thakuris live in the Lower Hills, who are related to the Indo-Aryan culture. They believe in Hinduism and rank themselves as the highest castes in Hindu society. The government of Nepal is mostly run by these castes. The Terai is inhabited by Charts and other Indian origin castes who share the Indian origin culture and traditions. However, the most diverse society is the Newars who live in the Kathmandu valley. They are rich with culture, traditions, music, cuisine, etc. Newars are the most ancient people whose antiquity goes back to the time of Gautam Buddha. They are the original inhabitants of the Kathmandu Valley. Before Gorkhali King Prithvi Narayan Shah took over the Kathmandu Valley, the Newars ruled this valley in three Kingdoms; Kantipur, Lalitpur, Bhaktapur (and Kirtipur). Kathmandu is now the capital of Nepal. Different caste people have been settling here. Newars may now are less in the numbers but are making a great impact on the nation's socio-economic, political factors. Newari culture and traditions still dominate the valley and have kept the country rich with festivals and occasions.

Newars are diverse within themselves. The caste system, hierarchy, class divisions, the division of labor, traditions, rites make themselves the most complex caste in Nepal. The Newar caste was divided by Jayasthiti Malla based on the division of labor, but according to time, the Newars have been changing.

Jyapu is the typical name for the indigenous farmer of the Kathmandu Valley. This ethnic race since the early settlements has established its own existence and recognition preserving its own indigenous culture, language, costumes, arts, literature, life styles, traditions, etc. This race has adopted agriculture as its main occupation, "Dhime" as musical instrument and Nepal Bhasha (Newari) as its mother language. In each festival, feasts and pageants 
inside the valley this society has the leading role. Jyapus live all over the Katmandu Valley. They are found wherever agriculture is done. Jyapus are mainly the farmers. Etymologically, the word Jyapu is derived from "Jya" as "Work" and "Phu" as "Capable." Those who are capable of working are considered "Jyapu"

\section{Objective and Methodology}

In the current debate of inclusion in Nepal the main objective of this paper is to explain the status of social, economic and cultural inclusion of Jyapus among Newar community. Specifically this paper explores the socio-economic and cultural situation of Jyapus of Lalitpur. It also further analyzes the relationship between Jyapus and other Newar communities in terms of social, economic and cultural exchange identifying the major dimensions of social, economic and cultural inclusion of Jyapus in broader social context.

The data for this paper have been generated from the Jyapu community of Patan City of Lalitpur district. Within four holes of the Jyapu group of population with quantitative and qualitative research methods in the city. With respect to area coverage, this study covered selected roles of city i. e. Chhayabahal, Lukhusi, Tanani and Nakabahil, where the concentration of the Jyapu population group is available. Each selected roles were divided into two to three equal clusters in which all clusters have equal chance to be selected based on systematic random sampling methods in entire roles.

Jyapus are mostly residing in the Patan city of the Lalitpur district. Jyapus are not found all poles of the Patan city in the Lalitpur district. This study concentrated only on the Jyapu residing roles i. e. Chhayabahal, Lukhusi, Tanani and Nakabahil. This type of population is residing separately in other roles. The study captured those ward and roles according to the systematic and multistage cluster sampling methods.

Applying the probability-sampling technique, four poles were selected in the city as a cluster. From the city, holes were selected from the multistage cluster sampling and divided into different clusters, where the Jyapus are concentrated. In the perspectives of sample coverage, it covered most of the Jyapus population in the sample population. Especially, the cluster sampling method was applied in this research, which is a more representative sampling technique of study population among the different clan groups of Jyapu.

The data collection methodologies in this research were Qualitative and Quantitative. Most of the data related to origin and culture were qualitative and the data related socio-economic was quantitative. Both Qualitative and Quantitative data were collected from Primary and Secondary sources. Secondary data were collected from many Jyapu organization like Jyapu Samaj, Lalitpur metropolitan office, records in respective ward offices, published and 
unpublished documents and relevant literatures from libraries, websites etc. Primary data were collected through the Household interviews, Interview with Key Informants and Nonparticipant observations from the field survey. The important data collection tools were household interview using interview schedule, key informant interview.

The mode of data analysis is also of mixed mode. According to the requirement of the research, extensive qualitative data were collected and analysed. In-depth-interview (IDI) with respondents, and key informants interview data were transcribed and summarized. Non-participants' observation data were also developed a narrative summary. Beside these, field notes and narratives of interview were summarized. The data entries of the quantitative data were computer entered immediately after the information collection task was completed. The post coding of the open-ended questions and manual data editing was performed before the data entry work began. The researcher had conducted electronic data editing after the data inputted in the computer. The variables, the variable labels and the value labels were added in the electronic version of the data, which are applicable for analysis.

\section{Social Inclusion of Jyapus}

In the paper Dhime Baja, Dhunya ra Jyapu Jati, there written, within Newar Community Jyapu occupy two third of the total population and they are the tribal community of the Kathmandu Valley (Shrestha, 2057 B.S.). Among contemporary Newar the most distinct sector comprises the Jyapu, a name broadly applied to Newar farmers, a group that is further internally stratified by numerous sub-castes (Slusser, 1998)

Slusser further says, the Jyapu is the least educated and least acculturated to national Nepali norms. The most traditional sector of Newar society, the Jyapu preserve and assiduously observe what are clearly ancient customs rooted in the Newar heritage. Some of these, like Guthi, can be traces back to the beginning of the written records of the Kathmandu Valley, and to the Neolithic period in India.

She further describes, most of the Jyapu cling to a distinct custom, carry their burdens suspended from a shoulder pole (not), as no other Nepalese do (Plates 25-27, 95) and are enthusiastic in the celebration of innumerable Valley festivals. Most festivals, linked to the calendar round of farming activities, reveal their agriculture origin. As the principal repositories of indigenous culture in the Kathmandu Valley, the Jyapus afford a window on its past.

Jyapu community is one of the major sub castes in Newar caste hierarchy and important group of the country. A cultural and traditionally rich community has high importance in the 
National and International level. To maintain its dignity, identity, heritage and culture, this community should be included in the other Newar caste group of the community.

The Jyapu is seen as the most acculturate group inside the valley according to literature reviewed. They seemed to be preserving the Newari culture and tradition up to date. Also, some scholars reported that they are politically, educationally and economically backward. However, some scholars have also figured out occupational transformation in farmers of the Kathmandu Valley. So the researcher is highly interested in finding out the present social, economical and the cultural conditions of the Jyapu dwelling inside Patan city.

\section{Social Inclusion}

Social inclusion is the removal of institutional barriers and enhancement of incentives to increase access of diverse individuals and groups to development opportunities. (DFID/World Bank, 2006:9)

Inclusion is a positive concept in the context of change and development of society, community and the nation as a whole. However, dualism between exclusion and inclusion persists in any society (Beallnd Piron 2005, in Dahal, 2009). History shows that the exclusion of various forms has remained a dominant feature of social life in many European countries as well (Haung and Island 2009, in Dahal 2009).

\section{Practices of untouchability and untouchability}

Table 3.1: Distribution of Respondents having Faced Untouchability Practices.

\begin{tabular}{|l|l|l|}
\hline Untouchability Practices & Number & Percent \\
\hline Yes & 84 & 36.36 \\
\hline No & 147 & 63.64 \\
\hline $\begin{array}{l}\text { Reasons for } \\
\text { Untouchability }\end{array}$ & & \\
\hline Hinduism & 9 & 3.90 \\
\hline Bias policy toward Jyapu & 59 & 25.54 \\
\hline Poverty & 76 & 32.90 \\
\hline Lack of awareness & 71 & 30.74 \\
\hline Others & 16 & 6.93 \\
\hline Total & $\mathbf{2 3 1}$ & $\mathbf{1 0 0}$ \\
\hline
\end{tabular}

Source: Field Survey, 2020

Among the total 231 respondents, 84 faced untouchability practice. But, the respondents 147 respondents, did not face the untouchability behavior. The causes of untouchability, 
respondents shared their views in this way: due to Hinduism 9 respondents due to bias policy toward Dalits 59 respondents due to poverty 77 respondents, due to lack of awareness 71 respondents and others 16 respondents. The Hindu religion followers Jyapus are orthodox in their religious beliefs with compare to the other religion followers as said the nine respondents during the field study. They said that Hindu religion followers discriminate them at the time of celebrating Machandra nath atra, they do not eat with them during the feast in the community and they order them to wash dishes.

According to Kul Lal Dangol those who are economically empowered and good educational profile did not face untouchability problem or face in a few quantities. He further justifies

I have my own Handicraft business, I am ex-president of Jyapu Samaj, Lalitpur and I am associating with many organizations including board member of Patan Multiple Campus. Equally, I am acquainted with rights and duties of the Campus. So, I did not feel untouchability in my place. So called high caste people also behave me properly and respectfully.

Mangal Maharjan (advocate and present president of Jyapu samaj, Lalitpur) also focuses on causes of equal behaviour to Jyapus as education and economic prosperity along with political position.

Table 3.2 Distribution of Respondents Caste based Discriminating is Reducing after the 1990s.

\begin{tabular}{|l|l|l|}
\hline Reduction of Untouchability Practices & Number & Percent \\
\hline Yes & 147 & 63.64 \\
\hline No & 84 & 36.36 \\
\hline Reasons for Reducing Untouchability & & \\
\hline Increased in Education & 191 & 59.13 \\
\hline Improvement in Economic Status & 103 & 31.89 \\
\hline Increased in Participation & 29 & 8.98 \\
\hline Total & 323 & 100 \\
\hline
\end{tabular}

Source: Field Survey, 2020

Among 231 respondents, 147respondents responded caste-based discrimination is reducing after the 1990s and only 84 respondents reported that they are facing same type of castebased discrimination as before the 1990s. In the reasons of reducing untouchability behavior, 103 respondents said due to increase in education,99 respondents said with the improvement in economic status and 29 respondents said that increased in participation, but most of the respondents revealed multiple response. 


\section{Discrimination against Social Institutions}

In the totality of 185 respondents, 56 respondents were found discriminated by religion and 129 respondents were not discriminated by the religion. Among the total 56 discriminated respondents by religion, all the respondents, which mean 56 respondents are found discriminated by Hindu religion.

Table 3.3: Population Distribution of Respondents Reported to have Discriminated by Religion.

\begin{tabular}{|l|l|l|}
\hline $\begin{array}{l}\text { Discrimination by } \\
\text { Religion }\end{array}$ & Number & Percent \\
\hline Yes & 56 & 30.27 \\
\hline No & 129 & 67.73 \\
\hline Total & $\mathbf{1 8 5}$ & $\mathbf{1 0 0}$ \\
\hline By which Religion & & \\
\hline Hindu & $\mathbf{5 6}$ & \\
\hline Total & & \\
\hline
\end{tabular}

Source: Field Survey, 2020

Among the 231 respondents, 133 respondents reported not having inter-caste marriage in their village but 98 respondents answered to have inter-caste marriage in their village. The inter-caste marriage was done in both hypergamy and hypogamy.

Table 3.4: Population Distributions of the Respondents having Practices of InterCaste Marriage.

\begin{tabular}{|l|l|l|}
\hline $\begin{array}{l}\text { Practices of Inter-caste } \\
\text { Marriage }\end{array}$ & Number & Percent \\
\hline Yes & 98 & 42.42 \\
\hline No & 133 & 57.58 \\
\hline Total & $\mathbf{2 3 1}$ & $\mathbf{1 0 0}$ \\
\hline
\end{tabular}

Source: Field Survey, 2020

\section{Discrimination against religious activities}

In the totality of 231respondents, 84 respondents were found discriminated while celebrating Machandranath Jatra and 147 respondents did not discriminate the reason for not celebrating together was, in the study area still 84 respondents were suffering from the concept of untouchability. 
Table 3.5: Population Distribution of Respondents Reported to have Discriminated on Religious Activities.

\begin{tabular}{|l|l|l|}
\hline Celebrate Machandranath Jatra together & Number & Percent \\
\hline Yes & 147 & 63.64 \\
\hline No & 84 & 36.36 \\
\hline Total & $\mathbf{2 3 1}$ & $\mathbf{1 0 0}$ \\
\hline
\end{tabular}

Source: Field Survey, 2020

Among the 231 respondents, 147 respondents reported that the high caste Newari people can eat food together prepared by Jyapus. While 84 respondens said that the higher caste Newars still want to maintain caste-based discrimination between them.

Table 3.6: Population Distribution of Respondents Reported to have cooked food Together.

\begin{tabular}{|l|l|l|}
\hline $\begin{array}{l}\text { Have a cooked food } \\
\text { together }\end{array}$ & Number & Percent \\
\hline Yes & 147 & 63.64 \\
\hline No & 84 & 36.36 \\
\hline Total & $\mathbf{2 3 1}$ & $\mathbf{1 0 0}$ \\
\hline
\end{tabular}

Source: Field Survey, 2020

In the totality of 231respondents, 160 respondents were found not discriminated while worshiping different gods and goddess within the locality by other Newars Whereas 71 respondents are discriminated. Because some older generation nears still believe in the concept of untouchability.

Table 3.7: Population Distribution of Respondents Reported having worship Together.

\begin{tabular}{|l|l|l|}
\hline Worship Together & Number & Percent \\
\hline Yes & 160 & 69.26 \\
\hline No & 71 & 30.74 \\
\hline Total & 231 & 100 \\
\hline
\end{tabular}

Source: Field Survey, 2020

\section{Political Inclusion}

In the context of type's role and influence in society, political participation needs to be analysed from several angles. Conventionallu, politics is understood to cover the science of governance in the public arena only. However, in Jyapu's context it is imperative that 
politics includes politics within the community because it is the place where they are excited by higher caste Newari peoples.

You's political participation is defined as participation in different types of socio-economis organizations at local level.

\section{Participation Level}

Among the total 231 respondents, 185 respondents were found participation in socioeconomic organizations at the local level, where 46 respondents were found no participation in local level organization.

Table 3.8: Population Distribution of Respondents having Participation in Socioeconomic Organizations at Local Level.

\begin{tabular}{|l|l|l|}
\hline Participation & Number & Percent \\
\hline Yes & 185 & 80.09 \\
\hline No & 46 & 19.91 \\
\hline Total & $\mathbf{2 3 1}$ & $\mathbf{1 0 0}$ \\
\hline
\end{tabular}

Source: Field Survey, 2020

Among the having participation in different types of socio-economic organizations at local level 118 respondents were engaged in microfinance. Likewise, 41 respondents were engaged in the women's group, 20 respondents were engaged in school management committee and 6 respondents were engaged in health management committee. These data indicate that a pus is not excluded in participation in different socio-economic organization.

Table 3.9: Population Distributions of the Respondents having participated in Different Types of Socio-economic Organizations at Local Level.

\begin{tabular}{|l|l|l|}
\hline Participated Organizations & Number & Percent \\
\hline Micro-Finance & 118 & 63.78 \\
\hline Women's Group & 41 & 22.16 \\
\hline School Management Committee & 20 & 10.81 \\
\hline Health management Committee & 6 & 3.24 \\
\hline Total & $\mathbf{1 8 5}$ & $\mathbf{1 0 0}$ \\
\hline
\end{tabular}

Source: Field Survey, 2020

\section{Economic inclusion}

Poverty in general seems to be understood in terms of material and money. However, it has been associated with relational and symbolic issues. Poverty vs. property sounds like a dichotomy. In broader sense, it has multidimensional facets. In the context of globalization 
and class-based concept of vertical hierarchy of the society, belongingness of class of a person is determined by appropriation of different forms of capital prevalent in the society and "the poor" are those who are unable to grab this capital, are belonged to the lower class. The inability to participate in society or in decision making, violation of human dignity, powerlessness, susceptibility to violence, lack of voice respect and self-esteem, isolation are some domain of poverty. So, poverty does not only mean lacking material resources to meet basic physical needs for survival i.e. basic standard of physical capacity necessary for production and reproduction but also incorporates the symbolic and cultural aspects. Lacking material resources, though immediate, is just one domain of poverty. The subsistence notion of poverty does not incorporate the context of poverty. Therefore, the appropriation of different forms of capitals and socio-economic interaction are the critical domain for understanding the vicinity of poverty. In our context, poverty is measured in terms of ownership of property and occupation of the people, and all other parameters are secondary.

\section{Economic Activities}

Newars are known as farmers. Before, farming used to be the main occupation of the Jyapu. They were termed valley farmer. However, the condition has changed a lot inside the valley. During the last 20 years, the urbanization has grown rapidly. Hardly a large piece of land is seen inside the city area. Internal migration has drastically increased the population density of Lalitpur and the haphazard urbanization has occured more population concentrated in the municipality. The farming lands are changing into huge concrete jungle, only less land is left for agriculture and farming in Lalitpur. At present some Jyapus are engaged in farming occupation. However, the situation is not the same as previous that only farming can satisfy all needs of households. So this occupation status of the Jyapu of the study area is studied here. The section is divided into two parts; Primary occupation and Secondary occupation. Following table gives the picture of the Primary occupation of the sampled household.

In 231 households, According to respondents 15 sampled households have their main occupation as Agriculture or farming. Majority janus in the study area i.e. 150 are engaged in different governmental and non-governmental services that indicate that Jyapus in Lalitpur are equally employed in governmental and non-governmental services in par with other Newars, 35 respondents are engaged in small or large businesses including Garment shops, Handicraft business, and 31 respondents are working as Manual Worker (wage labor) in construction areas, handicrafts man, etc. The once farmers of the study area have massively shifted their occupation from farming to other different occupation because they want to generate the bulk of money while selling land than working on it. The generated money from land selling; they have invested in their occupational fields. Only 15 respondents are working as farmers till today. 
Table No. 3. 10: Population Distribution of Sample Households by Primary Occupation.

\begin{tabular}{|c|l|c|c|}
\hline S.N. & Occupation & Number & Percentage \\
\hline 1 & Agriculture & 15 & 6.49 \\
\hline 2 & Service & 150 & 64.94 \\
\hline 3 & Business & 35 & 15.15 \\
\hline 4 & Manual work & 31 & 13.42 \\
\hline & Total & 231 & 100 \\
\hline
\end{tabular}

Source: Field survey, 2020

During the survey among the 231 sampled households, house rent and working abroad came out as the most common secondary income sources among the Jyapus. Jyapus have been lately selling most of their land, building big houses and renting them to students, migrants, etc. It's easy money. House rent business can come as the main secondaryoccupation among the Jyapus in Lalitpur 114 respondents have small business (shopkeepers) as their secondary occupation. Working abroad came as the second secondary source of income. Foreign employment presently applies to all caste people from all over the country and Jyapus are no exception to this. Forty-two respondent families have foreign remittances as their secondary occupation. And 75 respondents did not have a secondary income source. The following table describes the Jyapus with different Secondary occupation

\section{Conclusion}

This study has focused on examining the social inclusion/exclusion of Jyapus in Newar community from Socio-Economic and cultural Dimension of Jyapu Newars of Lalitpur submetropolitan city. It is concluded that majority of the respondents were included from their social-economic aspect and their cultural aspect. On average, all the respondents' socioeconomic and cultural conditions were seen satisfactorily, a minority of them were seen excluded. This study has also concluded that the respondents were participating in many local institutions. They have willingness to participate and other Newars also give them to participate in such activities. It has also seen that small numbers of other Newars treat Jyapus as a second class citizen in the community while celebrating Machandra nath atra and worshiping in different temples. Other Newars can easily accept cooked food prepared by Jyapus.

\section{Reference}

Acharya, M. R. (2002), Nepal Cultural Shift Reinventing Culture in the Himalayan Kingdom, Delhi: Adroit Publication, 
Bajracharya, D. B. (2030 B.S.), Lichhavikal ko Abhilekh, Kathmandu: Nepal, Asiali Adhyan Sasthan,.

Burbank. J. (1992), Cultural Shock! Nepal. A Guide to Customs and Etiquette, Singapore: Times Edition Private Ltd.

Dahal, D. R., 2009. Social Exclusion and Group Mobilization: A Case Study Of Yadavs And Tarai Dalits In Dhanusa District. Kathmandu: CNAS.

DFID/World Bank (2006), Unequal Citizen: Gender Caste and Ethnic Exclusion in Nepal, Kathmandu, DFID/ Wornd Bank

Gellner D. N, (1995), Constested Hierarchies: A collaborative Ethnography of the caste among the Newars of the Kathmandu Valley, Nepal (co-edition): OUP.

Gellner D. N, (2001), The Anthropology of Buddhism and Hinduism, London: Oxford University Press.

Isin. F. Engin, Patricia K. Wood (1999), Citizenship \& Identity, pp25-30, 2455 Teller Road, Thousand Oaks, California, 91320 : Sage Publication Inc..

Jyapu puchha, (1103 N.S.), Jyapu Smarika, Ombahal:Kathmandu.

Kabeer, Naila, (2000), Social Exclusion, Poverty and Discrimination: Towards an Analytical Framework, IDS Bulletin Vol.31, no 4, 2000.

Maharjan, S. (2004), Jyapu Jatiko Samajic, Sanskritic Tatha Aarthic Abastha: A Study of Imadole VDC, Lalitpur, Nepal, M.A. dissertation submitted to Department of Sociology/Anthropology, Patan Multiple Campus, Lalitpur, Nepal.

Millar, Jne, (2003), Gender, Poverty and social exclusion. Social Policy and Society, 2(3): 181-188

Muddiman, D. (1997). Understanding Community Librarianship: The public Library in National Dalit Commission, 2004, Kathmandu:Gatibidhi Sandesh (Bulletion),

Nepali, G. S., 1965. The Newars: An Ethno-sociological study of Himalayan Community. Bombay: United Asia Publication.

OOmmen, T. K. 2009. Evolving Inclusive Societies through Constitutions: The Case of Nepal." (A Paper Presented at a Seminar on "Social Inclusion Policies in South Asian States, CNAS/ T. U, SIRF, SNV/N, Kathmandu).

Regmi, D.R. (1966), Medieval Nepal. Part II, Calcutta-9 : Firma K.L. Mukhaupdhya, Sharma N. (2052 B.S.), Nepal Ko Janajati, Lalitpur: Sajha Prakashan.

Shrestha, H.L, (2057 B.S.), Newar Jatiko Swarupma Kehi Kura, Janajati Sthaniya Bikas Mantralaya, National Ethnicity Development Committee.

Silver, Hillary (1994), Social Exclusion and social solidarity: Three paradigm, International Labour Review, Vol.133, pp 532-572.

Singh, T.L, (2004), Jyapu Jati Mhasika Chhagu Adhyan, Dheme Pau: Year 4, Vol. 19, pp. 2-4.

Slusser, M.S, (1998), Nepal Mandala: A Cultural Study of the Kathmandu Valley, Vol. I, New Jersey: Princeton University,.

Taylor, Charles, (1998), The Dynamics of Democratic Exclusion. Journal of Democracy 9(4): 143-156.

Young, Iris Marion. (2000). Inclusion and Democracy. London: Oxford University Press. 